\title{
8 \\ The Essence of the Korean Model of Development
}

\section{Conceptualizing the Korean Development Model}

Below, in Fig. 8.1, I have attempted to construction, with a schematic map, what can represent a model of Korea's development. While Fig. 7.1 depicts how the course of Korea's development unfolded, Fig. 8.1 expresses what actually made the transformation possible, that is, the central elements of development.

In sum, the Korean development model starts with the four cornerstones. Based on these cornerstones, the economic realm and the socio-political realm of Korea each realized a 'compressed' developmental process with more or less common characteristics in each stage of development. The top row representing economic domain and the bottom row representing socio-political domain show a full range of Korea's development.

Choi, Joong-Kyung observes:

among the countries that were disconnected from Western industrialization up until the beginning of the 20th century, Korea is the only country 


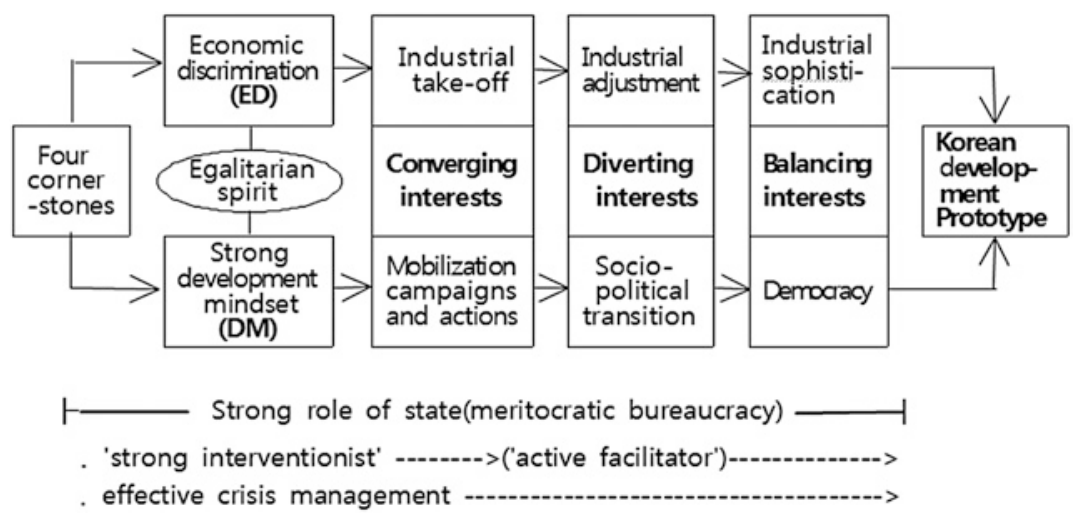

Fig. 8.1 Korea's development model

that achieved both Western industrialization and Western democracy. Both Israel and Singapore are also regarded as having achieved industrialization and democratization, but there were historical reasons ... Israel was formed by a Jewish population that came from Western industrial countries. Singapore was a small city economy and had been a base for the UK's East India Company for a long time, and this was exposed to Western-style industrialization from early on. ${ }^{1}$

In the economic domain, the rule of 'economic discrimination' (ED) was the principal driving force for growth during the rapid industrialization period. The rough timeline for 'industrial take-off' was the $1960 \mathrm{~s}$ and 1970s, while 'industrial adjustment' occurred in the 1980s and 1990 s, and 'industrial maturity' took place the period from 2000 up to the present day. As mentioned earlier, 'economic discrimination' is the concept coined by Professor Jwa, Sung-Hee. This concept is instrumental in understanding the success of Korea, particularly in the economic take-off period.

Meanwhile, in the socio-political realm, the emergence and expansion of a 'strong development mindset (DM)' in the nation was critical in terms of motivating individuals and mobilizing the general public to work harder in order to attain a better life and the modernization of the nation. There is no denying that the economic domain and the 
socio-political domain must have had a substantial correlation or interactions. In my mind, what reinforced the rationale and effectiveness of both the DM and ED was the 'egalitarian spirit' typical of Koreans up to now. If we recognize that ED and the strong DM were crucial factors for development, 'egalitarian spirit' is more of a psychological element deeply ingrained in people's minds that expeditiously matched well with those two factors to produce maximal outcomes.

I have already pointed out that Korea boasts notable historical continuity and homogeneity as a nation. In the twentieth century, Korea's liberation from colonial rule and the Korean War largely demolished the existing socio-economic hierarchy and the vested interests structure. After being devastated by the Korean War, the nation had to start again from scratch and everybody was literally on an equal footing. The Korean people were all very poor, so there were basically two tendencies: either people could resign themselves to their lot or they could try to do something special to get out of the misery in which they found themselves. Fortunately, the nation did not opt for the former because unlike many Sub-Saharan countries blessed with abundant natural resources and a favourable climate, making year-round farming possible, Korea's land was resource-poor, rugged and mountainous, making an easy lifestyle simply unsustainable. And a strong sense of egalitarian-mindedness in the people prompted them to jump on the bandwagon of social mobilization.

An egalitarian mindset was important because this encouraged competition and emulation among the people to 'keep up with the Jones', as if they were saying: 'If others can do it, why can't I?' People were envious of their neighbours' or acquaintances' wealth or success, and this made them exert greater effort to try to catch up with them. I think the can-do spirit of Koreans is rooted in this egalitarian thinking. It has also been observed that: 'Korea's development is also remarkable because it constituted development with equity, with rapid poverty reduction and no increase in inequality throughout the development process.' $^{2}$

In addition, socio-cultural norm that emphasizes 'saving one's face' and maintaining one's dignity, along with the typical 'shame culture', has contributed greatly to the emergence and expansion of a hardworking, self-sacrificing populace. As illustrated in Fig. 8.1, the period 
of 'industrial take-off' can be characterized as an era of 'convergence of interests'. The interests of the country's leader, the government, the people and companies converged, leading to phenomenal and unparalleled economic growth. In the early 1960s, Korea had just experienced the troubled government of Rhee, Syng-Man, who was ousted following popular opposition. The cabinet system administration that was newly formed also found itself unpopular and in turmoil, and as a result, the military, led by a group of young officers, staged a coup with the rationale of saving the nation.

The strong role of government based on meritocratic bureaucracy is the hallmark of Korea's success, particularly in the rapid industrialization period, but is also the overarching feature in the overall development of Korea that continues to this day. What started as the government's strong interventionist stance in the early 1960s over time underwent adjustments and changes so as to become that of an 'active facilitator'. But this does not mean that the government's function has basically 'weakened'; instead, it reflects changes in government policy.

What is not marked in the Korean development model diagram, but is deemed as another important feature for the success of the nation is the timely and effective management of crisis or, even better, taking advantage of a crisis. This notable feature has crystallized on many occasions throughout Korea's development path. Not only was Korea able to successfully cope with crisis time after time, but it also came out stronger than before. The responses to crises or challenges were bold and immediate. And Korea made many correct policy choices when confronted with big challenges or tasks. Even when some of these turned out to be failures, the government was on track to fix them.

The collapse of Rhee's government and the ensuing new government at the turn of the 1960s was in itself a crisis for Korea. But as it turned out, the 1960s marked an important turning point in relation to Korea's development. So, what enabled Park Chung-Hee's government to be successful in driving forward its policies? A combination of factors must have been in been in effect, but the 'right timing' of the advent of a new state leadership and the 'synchronization' of policies, national demands and aspirations, etc. should also be recognized. The test for the new 
democratic politics in Korea failed due to various reasons. The people were wary of politics, and uncertainty and instability prevailed. Park came from a poor peasant family and his style of leadership was perceived to be down to earth and in touch with the grassroots. Korea was at a low point in every aspect and people were willing to support and take part in new initiatives.

Meanwhile, because of North Korea's propaganda and the perception held by some South Koreans that North Koreans might be better off living under a communist state, there was a constant pressure on the government to outperform North Korea in terms of economic development. This was all the more reason for Park to vigorously launch the national modernization campaign in order to consolidate the legitimacy of his rule.

This was a time when the Cold War was at its peak, with the threat of North Korean communist military adventurism being very real. The ongoing Vietnam War was a stern reminder of what might happen in the Korean Peninsula. South Korea was in competition with North Korea on multiple fronts: economic, military, political and ideological. It was also in a fierce contest with the North to win the 'approval' of the international community. Korea depended heavily on the US for its military capability and national security, but this also represented a vulnerability for Park's regime.

There were also disagreements with the US in certain areas, such as Korea's pursuit of its export-drive policy instead of import-substitution. President Park was at times wary of a possible US military pull-out from the South, knowing all too well that the US security commitment to Korea hinged on the decisions taken in Washington, DC and that it should not be taken as a given. This led Park to hasten economic development in order to try to acquire industrial capability including defence.

'Modernization of fatherland', the motto of Park Chung-Hee's government, was timely and appropriate for the nation, and it would have been hard to argue against its logic, given the circumstances in Korea at the time. Rather than being populist and trying to cater to the short-term needs of the masses, Park emphasized the great challenges that lay ahead and the magnitude of the work that needed to be done to pull the nation 
out of poverty. The term 'modernization' implies moving from 'backwardness' to modernity, realizing economic development and adopting advanced modes, systems and institutions necessary to upgrade the nation so as to join the ranks of the rich nations. Hence, the government asked people not only to support the vision and policies but also to actually participate vigorously and physically in the 'mobilization' campaigns.

But the effectiveness of winning popular support and generating social mobilization hinged on the government's leadership and performance, and the development momentum of the nation was sustained because the government was able to deliver concrete results promptly. During the take-off period, Korea's policies and industrial structure underwent big and continuous changes. Korea's conversion from protectionism and import-substitution in the 1950s to export-oriented policies in the 1960s is hailed by many experts as the most dynamic transition since the Second World War. It was in 1962 that the first fiveyear economic development plan was launched. The targeted goal of economic growth was set at a very high level of $7.1 \%$ average annual growth, but the actual growth rate attained exceeded this, reaching 8.5\%. The second five-year economic development plan (1967-1971) yielded an even more remarkable result of $9.7 \%$ average annual growth against the original goal of $7.0 \%$.

What was also remarkable about President Park was that he took very bold economic measures against the advice of international organizations and principal donors by pursuing an export-drive policy, establishing Pohang Iron and Steel Company (POSCO) and building the eight-lane Gyeongbu Expressway. Choi, Joong-Kyung, who served in Korea's Ministry of Finance and the World Bank, observed that:

at the time, the projects seemed like nonsense and the tasks appeared impossible. President Park Chung-Hee was not an economist. He witnessed the success of other countries that faced similar situations as Korea and he believed in his intuitions. The case of West Germany (which had success with an export-drive policy and hardly had any natural resources) caught his attention. The unified Germany still continues to adopt [an] export-drive policy. As a small country with a small domestic market and with scarce natural resources, such a policy is almost inevitable. ${ }^{3}$ 
According to Choi, for an economy to achieve successful development, four basic elements are required: a strong and stable leadership with a clear vision; well-organized economic development plans; a competent bureaucracy to carry out these plans; and the financial resources necessary to execute meet them. In the case of Korea, these conditions were met and 'without any doubt, the late President Park Chung-Hee was the architect who exerted leadership and created the strong foundation of the modern Korean economy. The zeal for education and a competitive and objective civil service exam made it possible to recruit and maintain a competent bureaucracy. Through visionary leadership and the efforts of an efficient bureaucracy, it was possible to establish highly effective five-year economic development plans'. ${ }^{4}$

In the 1950s, Korea was seen as a 'hopeless' and high-risk country, with the possibility of war breaking out again in the eyes of foreign agencies, including the United States Agency for International Development (USAID) and the World Bank. Korea was unable to obtain the necessary loans to push forward with its economic development scheme in such circumstances where Samuel D. Berger, the US ambassador to Korea, made a negative report to his headquarters regarding Korea's development plans and the World Bank was equally reluctant to extend financial assistance to Korea. Despite the unreceptive mood of the international community towards Korea's needs, in 1962 Korea was finally able to sign a commercial loan agreement with West Germany. By the terms of agreement for a loan of USD 150 million, Korea had to send nurses and miners that West Germany needed and the salaries of the workers were set as collateral. ${ }^{5}$

The first job assigned to the Korean nurses who were sent to an alien country was cleaning stiffened dead bodies. The miners worked so painstakingly hard, risking their lives in caves over 1000 metres deep underground fighting geothermal heat. The Korean workers' zealous work deeply impressed the people of West Germany and so President Park was invited by President Heinrich Lübke to visit West Germany in December 1964. Anxious to greet their President, who has come all the 
way to West Germany to meet them, Korean miners and nurses gathered in an auditorium all dressed up: the miners in suits and the nurses in traditional Korean dress. Prior to the Korean President's speech, they all began singing the Korean national anthem but none of them could finish the song because they were all sobbing. President Park put his prepared speech into his pocket and said repeatedly 'let's work hard'. He went on 'let's work hard until our bodies turn into shatters so that our sons and daughters would not be sold to a foreign country'. The Korean workers cried out 'we will do anything. Please help our country, please help our President', as they knelt down and bowed low to the ground for the President of West Germany. Leaving behind sobbing Korean workers, on his way back to the hotel, President Park could not hold back the tears. President Lübke give him a handkerchief and comforted him by saying 'we will help you; the people of West Germany will help your country' 6

Through such hardships and the sacrifice of the people, Korea was able to build the stepping stones towards modernization. In addition, sending troops to Vietnam helped accelerate the economic growth of Korea as the soldiers' combat allowance money was used to fund the Gyeongbu Expressway. The Korean government also obtained a reparation payment of USD 500 million and commercial loan of USD 300 million from Japan following the normalization of diplomatic ties with Japan in 1965. The payments were used to build the Pohang Iron and Steel Company and other investments. Money earned by Korean construction workers from construction sites in the scorching desert heat of Middle East in the 1970s was another valuable foreign currency inflow for Korea. Fabric, shoe and wig factories were packed with teenage boys and girls who were saving money to pay for their younger siblings' education.

And yet another drama unfolded when Koreans achieved democratization. There are two common misperceptions held by many foreigners when it comes to the state of Korea's democracy. One is that Korea is still run by an authoritarian or non-democratic regime and the other is that Korea was democratized long ago and it achieved development under democracy. But neither is the case. First of all, the Korean democratic movement ran its full course and could possibly be the most 
successful case of a Third World nation-turned full democracy since the second half of the twentieth century. Korea's compressed development featured 'compressed democratization' in addition to compressed economic growth and transformation. It would be no exaggeration to say that the level and dynamism of democracy exhibited by South Korea is highly exceptional in the non-Western world.

Korea's compressed democratization was fuelled by democratic uprisings or movements, although even during the absence of such events, there were ongoing awareness and a drive for democracy in society, albeit in a subdued fashion. In the post-war era, the first democratic movement erupted in 1960 against the Rhee Syng-man regime, culminating in the 19 April Revolution that finally toppled the government. But the new democratic government that was formed was seen to be incompetent and powerless, and was overthrown by a military coup just after a year.

If President Park lacked full legitimacy because he had taken power through a coup, his delivery on impressive economic development more than offset this, as shown by his landslide win in the 1967 presidential election. But he faced increasing opposition to his prolonged rule in the 1970s, as he announced a plan to amend the Constitution to allow him to run for a third term in October 1972. The new Yushin Constitution was legislated in December of that year. Park was assassinated in October 1980 by his aide, the chief of the intelligence service. The assassination is largely considered to be an outcome of a collision between the repression of Park's regime and the resistance of the democratization movement, which was preceded by years of confrontations and escalating tensions in political parties under the Yushin system. After Park's assassination, the prospect of democratization appeared to be evident in South Korea.

During the early years and up until the mid-term of Park's rule, successful economic development enhanced the legitimacy of the regime. However, by the time of Park's death, the regime had lost much of its popular support due to changes in people's attitudes and values brought about by economic growth and the enhancement in people's standard of living, and also because Park reinforced coercion to prolong his rule. There were high expectations that the end of Park's dictatorial rule 
would open a new era of democracy, giving rise to the 'Seoul Spring', which was the period from 26 October 1979 to 17 May 1980.

But the 'neo-military forces' snatched power from the transitional government with a military coup and imposed martial law on 17 May 1980. General Chun Doo-Hwan soon became President and after his term finished, Chun's chosen successor, Roh Tae-Woo, a retired general and an army academy classmate, took over. In the meantime, a massive anti-government uprising occurred in the city of Gwangju on 18 May 1980, which is referred to as the Gwangju Democratization Movement. During this period, citizens rose up against Chun's dictatorship. During the course of the uprising, citizens took up arms by raiding police stations and military depots to oppose the government and the imposition of martial law, but were ultimately crushed by the army. Hundreds of people died in the process. There was another major democratic uprising in June 1987, which pressurized the regime to accommodate some institutional and policy changes demanded by the people and the opposition.

The democratization movement in the 1980s was no longer limited to the student and the dissident movement. Instead, it was aligned with social movements and particularly with the labour movement. Moreover, the opposition party which had been excluded from the political scene re-entered the political arena following the general election in 1985 and expressed opposition to dictatorship and support for democratization more clearly. Accordingly, the democratization movement was able to muster the largest coalition of social and political forces comprising workers, opposition party and dissidents, and students.

Although the democratic transition ended up in the emergence of the Roh Tae-woo regime, which succeeded the Chun Doo-Hwan regime, the political environment of Korea did change after the transition. Above all, the constitutional system began to operate normally under the amended Constitution in 1987 and subsequently, the arbitrary exercise of the state's power was considerably reduced. In addition, political and civil society, which had been repressed by authoritarian rule under the dictatorial regime, also became normalized due to democratization. 
A normal political party system based on popular support was created, although it was under the influence of 'regionalism', and civil society also regained autonomy and developed rapidly afterwards.

The election of Kim Young-Sam, the leader of the democratic movement, as Korea's President in 1993 ushered in a new era of civilian rule. Then, after ten years of democratic transition since 1987, Kim DaeJung was elected President in the fifteenth presidential election held in December 1997. The emergence of the Kim Dae-Jung government was a historic feat because it marked the first 'parallel' regime change by election and also because the regime change was made by a democratic opposition party. The Kim Dae-Jung government was followed by a successive liberal government led by President Roh Moo-Hyun, who came to power in 2003.

After ten years or two terms of rule by liberal-progressive party leaders, the political landscape of Korea shifted back to conservative party rule as a businessman-turned politician Lee Myung-Bak from the conservative party became President in 2008. Then, the conservative party's candidate Park Geun-Hye, the daughter of the late President Park Chung-Hee, won the subsequent presidential election to become the first female Korean President in 2013. However, Park was implicated in a corruption scandal and faced massive public demonstrations demanding that she step down. She was removed from power after being impeached in March 2017.

The liberal party opposition leader Moon Jae-In became the new President in May 2017. Likewise, the political pendulum continues to swing back and forth between the conservative and liberal political parties since the peaceful transition of power was first realized in Korea in 1998.

Going back to Fig. 8.1, I have pointed out that in the 1960s and 1970s, the interests of the government and that of the people and businesses largely converged, producing positive synergy effects that led to high economic growth. But afterwards, the bond or unity between the government, corporations and the populace loosened, although it did not diverge strongly to cause instability of the country. 
What characterized this era of the 1980s and1990s is, I think, 'diverting interests'. I chose the word 'diverting' for a lack of better word, to avoid the word 'divergent'. This is to suggest that the interests of the government, the people and businesses started to 'differentiate' somewhat, but were not really in conflict with one another.

By this time, South Korea has extricated itself from poverty, so economic stability, distributional justice, workers' rights and democracy were higher priorities. One of the signs of change was that the Korean private business sector, especially the large business conglomerates, the chaebols, now wanted to be more autonomous vis-à-vis the government. Labour unions, opposition political parties, intellectuals and social activists wanted their voices to be heard and increasingly confronted the government and the establishment.

During the Park Chung-Hee era, modernization was the single most important goal of the nation and most of its energy and resources were devoted to achieving economic development. But afterwards, many things were set to change. The early success in economic growth is deemed to have set off a chain reaction of: economic development; social, political demands and changes; economic policy adjustments; evolution of democratization and social dynamism; deepening of economic reforms and sophistication of industrial structure, and so on.

But Korea might have started celebrating too early and was complacent without ever suspecting what was to come. To the shock of the whole nation, Korea was on the verge of bankruptcy and had to receive a financial bailout from the IMF in December 2007. Moral hazard and problems in corporate governance on the part of big business, the weakness of the government and its failure to monitor and regulate the problems, as well as excessive borrowing and spending by the people gave rise to a major crisis. This led to a change in the tide, the reassessment of unfettered free market economy and the re-alignment or rebalancing of interests. The 1997 Asian financial crisis and the 2008 global financial crisis were stern reminders to Korea that a sound regulatory role of government is very much in order and that economic globalization poses such a grave, immediate and extensive risks to economies if they lack the necessary discipline and governance. 
For Korea, this was an occasion to become 'united' once again. To help the government pay back the IMF debt, the Korean people voluntarily launched a movement to donate gold. This was in effect a revival of the Saemaul Undong. Such an act of the people giving up their personal possessions for the public cause is unheard of in the world history. The business conglomerates had to undergo serious restructuring, and they became more conservative in their investment activities. The last phase of 'industrial sophistication' is still an ongoing process.

Politically, Korea has become a full democracy, while economically it is faced with increasing global competition. The interests of various players or entities in Korea can be said to be in the 'balancing' stage. They do not converge to the extent that they did in the 1960s or 1970s, but nor are they as divergent as was sometimes the case in the 1980s or 1990s. We can say they are somewhere in the middle.

Koreans have responded and adapted appropriately to challenges and crises. The 'Palli Palli (hurry hurry)' culture, which is typical of the Korean people, is deemed to have been instrumental in bringing about the rapid development. There is a tendency that people cannot stand staying idle or doing nothing, because this will make them uneasy as if some kind of penalty will be incurred for doing so. They feel more comfortable keeping themselves busy.

Without question, the strong role of government was essential in propelling the nation forward. The government was effectually interventionist' during the high growth period, but even during later phases, its active role persisted in the form of engagement in regulating and 'facilitating' the national economy, which has become increasingly complex to manage.

Jongryn Mo and Barry R. Weingast explain Korea's development using an analytical method devised by North, Wallis and Weingast (2009) referred as the 'NWW approach'. They attempt to explain how the transition of Korea's political economy from an underdeveloped to a developed country took place, that is, from a 'natural state' or 'limited-access order' to an 'open-access order'. ${ }^{7}$ Countries have different levels of openness or accessibility in their political order and economic order, and when the disparity between these two becomes large, it causes social tensions that require 'rebalancing' measures. ${ }^{8}$ 
According to the authors, Korea's successful development came about because an increase in economic access was followed by a corresponding increase in political access (democratization). ${ }^{?}$

\section{The Four Cornerstones of Development}

\section{Land Reform}

The first major impetus for change in Korea came from the land reform, that was a powerful and innovative policy based on the land-to-tiller's and market-oriented principles. Korea's land reform is internationally known as one of the most successful cases of its kind. The Korean case of land reform stands out as it was rapidly implemented, resulting in the collapse of landlords who dominated rural communities at the time. This is in stark contrast to the disappointing results seen by many other developing countries in their land reforms.

Park, Hyung-Ho observes that:

Korea's land reform was implemented based on a compound combination of political, social and economic factors. In the way that Korea abolished a semi-feudal tenancy system as well as landlordism in a relatively short period of time, Korea's land reform is acclaimed as the most successful case of land reform all over the world. Therefore, a redistributive land reform at an early stage of development can be a crucial means to lay the basis for agricultural productivity gains while enhancing growth and poverty reduction prospects. Such government interventions can lead to both equity and efficiency gains. ${ }^{10}$

When Korea was liberated in 1945, it was an agrarian economy in which most of the population were tenant farmers without ownership of farmland. In view of the slave-like status of the tenant farmers who were subordinate to landlords, the 1948 Constitution that established South Korea guaranteed private land ownership and proclaimed the adoption of a capitalist economic system. While the land reform's social objective was to free the populace from the shackles of servitude, its 
'economic objectives were to improve agricultural productivity and the income of farmers by dismantling the oppressive tenant farming system, to encourage reinvestment, and to provide incentives through ownership of land and production'. ${ }^{11}$

Korea's land reform and the Korean War in effect brought about equality in income and property in Korea. The vested interest class of landlords was disbanded and educational opportunities were extended to the people, thereby promoting greater social migration and an egalitarian society. The land reform had a huge impact on Korean society. The proprietary class, the landowners, inherited lands handed down to them generation after generation from their ancestors, while tenant farmers remained where they were, leading to 'the rich get richer, the poor get poorer' phenomenon. But with the sudden collapse of the proprietary class, the conflict between these two classes also came to an end.

The land reform that was undertaken during the time of war was considered the most important measure during this phase of development. The government purchased the land and redistributed it to farmers in consideration of its market value. The government bought land by issuing land securities to the owners, and the farmers paid for the land in kind by instalments. In South Korea, landlords were compensated, unlike in North Korea, where land was confiscated and redistributed forcefully.

The land reform offered the chance for farmers, who made up about $75 \%$ of the Korean population, to farm on their own land. Being given the right of ownership was another big change for the vast majority of the populace. In itself, the reform did not have an immediate impact in terms of increases in agricultural production and income, due to the fact that war broke out and the new independent farmers, unlike the past landlords, lacked the necessary funds to invest in agriculture. However, it had a considerable impact in promoting the capitalist system and economic development in South Korea in the 1960s and afterwards. It helped South Korea nurture a capitalist society by giving property rights to farmers, unlike in North Korea, where collective farms were the norm. The guaranteeing of private farmland ownership in effect also created the necessary conditions for the guaranteeing of private property rights in other economic activities. 
An important point to note was that the Rhee government promoted both land reform and education reform at the same time, so that human capital could be successfully accumulated in Korean society, and this led to successful industrialization after the 1960s. The land reform and education reform produced synergistic effects.

It has been pointed out that thanks to the land reform, farmers were able to increase production and own what they farmed. They could think of climbing the social ladder and becoming rich. That's how they worked harder and created more wealth. Thus, it laid the groundwork for economic development and overall social development. ${ }^{12}$ Scholars have recognized that among the fast growing economies in the world, the case of South Korea, which has exhibited a remarkable degree of overall fairness in terms of income distribution, is exceptional. Many Korean experts argue that the roots of such success should be traced back to President Rhee Syng-Man's land reform, as there is a recognition that Korea was able to embark on a modernization path as an egalitarian society without this tension between the classes. Under such conditions, the possibility of acute conflict between the classes that has commonly occurred during the course of the progression of capitalism was shielded. It is said that this is the biggest benefit that Korea derived from the land reform. ${ }^{13}$

In the case of East Asian countries like Korea, Japan and Taiwan, the successful land reform helped bring about a large middle class, which acted as a cornerstone for economic growth and a social 'buffer' or balancer. This is in a stark contrast to many Latin American countries, where such a wide gap between the rich and poor exists due to their failure to properly enact land reform. The effective abolition of the social class system in Korea led to the realization of equal opportunities for all, and this in turn later gave rise to the spread of a 'can-do spirit' typical of Koreans.

Hyung-Ho Park states the lessons learned from Korea's experience of land reform: (1) the resistance of the privileged class on behalf of landlords should be overcome; (2) land reform should be accompanied by follow-up measures to ensure an increase in agricultural production and farmer households' income; (3) educational reform should be promoted 
concurrently to maximize the social benefits of land reform; and (4) the government's ability to implement reforms is important. ${ }^{14}$

\section{Empowering the People}

As I have pointed out earlier and illustrated in the Korean development model in Fig. 8.1, strong development-mindedness (DM) and ED were the two key drivers of Korea's sustained development. What propelled and reinforced these two elements further was the egalitarian spirit of Korea that was fostered during this time. In turn, the government's policy of 'empowering' people, along with the land reform, significantly contributed to the burgeoning of this national ethos.

The Korean government, in the circumstances in which it found itself and with the means at its disposal in the 1950s, was naturally inclined to pursue 'miserly' policies that sometimes called on the populace to do its part or help out the country. This is in stark contrast to many Sub-Saharan African countries that in effect use the plague of their people and poor state of their economy as leverage to get more offerings or concessions from donors. Korea tried to turn things around by itself through self-reflection instead of 'outsourcing' the burden of finding solutions to its problems to the international community. This 'outsourcing' trend, rather than diminishing, is seen to be becoming more pronounced in Africa.

Because Korea was not only devastated by the war but was also poor in terms of its natural resources, it had to rely heavily on foreign aid. With the massive flow of aid, the society developed a dependency syndrome that was seen by the government and intellectuals to have reached an alarming level and was having a very negative impact on the country. In such an environment of poverty and despair, men became idle, drinking and gambling their life away, while women did most of the household chores and laborious work.

The campaigns to empower the people led by the government had two purposes: other than the need to motivate and instil a work ethos in the people, there was a requirement for large-scale labour mobilization for pressing public works like land reclamation and reforestation. 
Because of Korea's lack of fuel due to its dearth in natural resources, the practice of timbering was widespread, meaning that many hills and mountains in populated areas were barren. This caused perennial flooding following heavy rainfall, accompanying mudslides, and sanitary and environmental problems.

Something had to be done to rectify this state of affairs, as well as to address people's problematic behavioural and 'mentality' issues, and the response came in the form of 'empowering the people'. This campaign started as early as the late 1940s under the Rhee government. The government wanted to change people's mindsets and values, and infuse a new work ethos: nothing would be free and everyone had to work hard; people were asked to work for food under the government-led projects and they were paid in wheat flour given by the US as aid. The materialization of such a policy showed the willingness of the people to change and empower themselves.

This kind of environmental protection public works initiative turned out to be a resounding success. The government was not only able to get people to participate in it actively, but also managed to sustain it in the long term. Preservation of the country's greenery through the planting of trees became a 'norm' for the people, and this public campaign has survived to this day. Nearly 21 million people participated in the land reclamation and reforestation programme led by the government. Over ten billion trees were planted over 30 years, bringing Korea's once-desolate landscape back to life. South Korea had been barren of trees after years of excessive deforestation and war, but trees once again covered $65 \%$ of the country. It was a remarkable achievement and the opportunities to make a living and to be rewarded for hard work helped establish a new set of values that would serve Korea well during its rapid development. ${ }^{15}$

I believe that the success of programmes to empower the people provided a useful basis for the Saemaul Undong that was launched in the 1970s. The former were the government-driven projects to conduct specific tasks, while the latter was essentially a bottom-up-style people's voluntary movement with the government's guidance and backing. The benefit of this was that it made people realize the value and necessity of collective work, and become used to the new culture of the 
mobilization of the workforce that was absolutely necessary at the time to initiate effective development.

It was not only the government that tried to empower the people. The need to 'enlighten' the people was perhaps felt widely across the nation and certain entities were engaged in this effort. One institution that is renowned in this field is the Canaan Farmers School, which specializes in mindset change training. It is founded on the Christian faith, with the goal of creating a humanistic society and prosperous future through moral value education, community education and leadership education.

While the school was formally established in 1962, its origins can be traced back to a model village that was created in 1931 by the founder of the School Kim, Yong-Ki. At the time, Koreans were suffering from Japan's severe colonial oppression and he led a farming movement, which was in a way a nationalistic movement to bolster people's self-esteem, determination and hope. The vast majority of the people were farmers and the leader of Canaan farmers' movement saw a fundamental national challenge in the form of the mindset of the people, and waged a fight against the shortcomings of the populace, like powerlessness, idleness, over-indulgence in drinking and dissipation. He embarked on the farmers' enlightenment movement in a bid to change the culture of dishonesty and vanity. He claimed that independence would come about faster when there were a growing number of people with the right attitude. The motto was 'pioneering spirit'.

The Canaan Farmers School is said to have been an inspiration for President Park Chung-Hee to launch the Saemaul Undong. As Korea had attained high economic growth and the agriculture sector continued to shrink, the focus of this school also underwent some changes. I remember in the 1980s, when I was in my twenties, Canaan Farmers School was considered as a sort of mental-reform institution teaching the values of self-discipline, thrift and diligence, social responsibility and ethics, etc. Many groups of people from various backgrounds, including public officials, businessmen, students, leadership course trainees and farmers, entered the school to be trained. Individuals also enrolled on a voluntary basis. Decades later, the school extended its 
scope of activities to international programmes or development projects both domestically and in foreign countries.

There were other similar mindset reform campaigns led by various religious entities and social groups, like the Catholic Church's revival of the moral rearmament movement with the motto 'it's my responsibility'. In Korean society, you can very often see civil society groups expressing slogans for the reforming of citizens' mindsets. This means that Korean society is basically a self-reflecting society and that the empowerment of the people is self-generated by the people. This is the opposite of how the 'empowerment' of the people is understood and pursued in some African countries, where grants to a large segment of poor people are provided in a way that makes them more dependent on the state.

\section{Revolution in Education}

It would not be an overstatement to say that Koreans understand the value of hard work and education probably more than anyone else. In the 1950s, illiteracy among adults was a staggering $77 \%$, and an all-out war was waged to fix this. In 1954, the first campaign of the war was launched by making primary education compulsory. Primary education was deemed most important because in this period in one's life, people learn the basic knowledge and social skills that serve as the foundations for human development. What is even more important is that it made primary education accessible to girls. So, lack of money was no longer an obstacle to receiving primary education.

After 1945, enrolment in primary schools grew rapidly. In less than a decade, Korea reached an enrolment rate of $83 \%$ in primary education, up from only $54 \%$ in 1945 . By 1959 , primary education was within reach of everyone. The war on illiteracy was waged in community centres scattered across the country. Millions of adults learned to read and write in schools with US assistance. It was made compulsory that illiterate adults took up more than 200 hours and over 70 days of education. In five short years, illiteracy rate among adults fell to just $22 \%$, which was a remarkable achievement. Within a decade of the launch of this 
mandatory education, the number of primary schools grew from 2800 to 4600 , and students from 1.36 million to 3.6 million. Universities also grew rapidly, from 19 to 68, with university students increasing from 8000 to 100,000 . Numbers of middle-school students grew by 10 times, high-school students by 3.1 times and university students by 12 times.

When we look at the government budget in the 1950s, the portion spent on education accounted for about $20 \%$ of the total, which is seen as an impressive statement of the government's commitment to education, even in a time of war when defence spending took up about $50 \%$ of the entire budget. This laid the groundwork for what turned out to be an icon of Korea: a nation enthusiastic about education. It is often said that the ingredients for Korea's success lie in its human resources. About 17 years ago, when a Korean law-maker who was visiting Cote d'Ivoire was asked by his counterpart what brought about Korea's economic development, he replied without hesitation that it is the education and the will of the people'. I would add to this that what really made the difference was the education that went beyond regular academic studies, like inculcation and regeneration of social values, and pragmatic and action-oriented courses like technical training.

\section{Governmental Reform}

While three of the 'four cornerstones of development'-the land reform, empowerment of the people, and a revolution in educationwere launched during the Rhee Syng-man government, governmental reform, namely the creation of Korea's National Tax Service, was undertaken during the Park Chung-Hee government.

In 1966, the National Tax Service, the first of its kind, was established. If educational reform was the war against illiteracy, establishing the National Tax Service was waging a war against deep-seated corruption in government and business. This was symbolic of the government's efforts to undertake self-reform to tackle corruption and improve services. The effect of the reform was almost immediate, as tax revenues grew by $51 \%$ on average from 1966 to 1969 . The increase in tax revenue provided critical fiscal resources and helped Korea to become self-sustainable. 
During the time of President Park's tenure in office, various efforts were made for nation-building and accordingly, many government agencies, mechanisms and policies were created or launched. To name just a few, within the five years since Park Chung-Hee assumed power, the Economic Planning Board, the Rural Development Administration, the Ministry of Construction, the Board of Audit and Inspection, and the Ministry of Science and Technology were established. These were all very important and foundational organizations, but President Park is said to have particularly favoured the National Tax Service, and this organization soon became an all-powerful and authoritative government watchdog and enforcer of national revenue collection.

It is widely accepted that a meritocratic bureaucracy was critical for Korea's fast development and this is one of the things that set Korea apart from most other developing countries. The advent of disciplined, capable and patriotic bureaucrats may have been bred by the Korean culture, but this would not have been possible in Korea without strong leadership and the commitment of the ruling elites to motivate government officials in such a way. Recognition and promotion were effective tools that were used to maintain the meritocratic bureaucracy.

The 'governmental reform' - in a wider context of rejuvenating and empowering the entire bureaucratic circle to become substantially more goal-oriented and 'functional' - took place during the time of Park's government. As we have seen, the principle of 'incentives and punishment' that the government applied to businesses was also in fact applied to civil servants and, in this regard, to the general public as well.

\section{On Koreans' Temperament and Egalitarianism}

As Korea went through a half-century of upheaval to enter the mature stage of development, it seemed timely that Koreans looked back and assess what their ingredients of success were with greater depth of perception. Over the years, a number of interesting works by Korean experts shedding light on the 'secrets' of the Korean people's temperament have emerged. Among them are Baek, Suk-Ki's 
Koreans' Success DNA (2007) and Shin, Gwang-Chul's Extremist Koreans, Extreme Creativity (2013).

What is interesting to note in this regard is that recent efforts to find explanations for Korea's economic or developmental success from a Korean perspective are being increasingly drawn to the domain of national traits. Early observations both within and outside of Korea cited the general traits of Korean people as 'hard-working' or 'diligence'.

But recent studies on the temperament of Koreans have become more sophisticated. Baek observes that this temperament has evolved over the course of Korea's history. Traditionally, Koreans were known for their paternalism, veneration of literature, respect of traditional and moral values, respect for the elderly, originality and optimism, emotional sensitivity, etc. But on the other hand, they also showed vanity, disunity, disregard for economy and pragmatism, laxity in terms of morality, obsessions with the past, lack of ambitions, lack of rationality and courage, irresponsibility, self-righteousness, exclusivity and ignorance of the rule of law. ${ }^{16}$ However, as the people entered into a dramatic phase of transformation in the 1970s, they showed active and aggressive traits, blending Western rationality with their traditional values. Veneration of literature, social orderliness, courage, a challenging spirit, love of peace, ethics, paternalism, a taste for distraction and amusement, an egalitarian spirit, democratic values, creativity and humour were stressed. At the same time, emphasis on face-saving, emulation and accommodation of others, intervention in the affairs of others, superstitions, lack of cohesiveness, collective egotism, dichotomic thinking of what is just and unjust, and hastiness were pointed out as shortcomings. ${ }^{17}$

Baek lays out six uniquely Korean facets that drive Koreans to try to become 'number one' in the world: (1) emulating and meddling in others' affairs in order to surpass them; (2) employing full creativity and dynamism to create new values; (3) a bibimbap (mixed rice) culture of fusion and harmony (the icon of today's network society); (4) a palli palli (quick, quick or hurry, hurry) temperament, which is 'an advantage in the digital age'; (5) a shinbalam (love of merriment) spirit serving as an impetus for the creation of new cultures; and (6) a zealous passion for education. ${ }^{18}$ 
Shin, Gwang-Chul's work is much more historical, detailed and analytical in terms of identifying and tracing the many originalities and facets of the Korean national ethos. He traces back as far as the ancient Korean kingdoms and highlights Korean cultural heritage as evidence. Here, the word 'extremist' or 'extremism' is used as a term to depict not religious or ideological radicalism, but how Korea has accommodated and embodied different things that are so different or in contrast to each other. Reading his book, I came to realize that the Korean national flag is a good reflection of this: the circle in the middle of the flag is derived from the philosophy of yin and yang, the balance and harmony of opposing forces.

According to Shin, Koreans have traditionally accepted 'extremities' or 'opposites', and this would be quite unique in this world. The characteristics of Koreans are elaborated and summarized as the following four points: first, Koreans accommodate totally different and opposite elements, internalizing and socializing them; second, Koreans have the dynamism to 'traverse' between the two extremes to create new things; third, Koreans provide 'middle grounds' to avoid collisions between the extremes; and, fourth, Koreans have the ability to 'integrate' differing factors to bring about a greater whole. ${ }^{19}$

For example, when foreigners are asked to name one single trait that best describes Koreans, many would say it is the palli palli temperament. There are both positive and negative connotations to this, such as diligence, motivation and a positive work ethic, but also hastiness, quick-temperedness, social stress, etc. But interestingly enough, on the opposite side of palli palli, there is this trait of 'composure and perseverance' that is typical of Koreans. Patience, endurance and a 'never give up' spirit have been the hallmark of the Korean people. On the surface, these two may seem to have no links whatsoever, but what drove Koreans to achieve success was not only the palli palli spirit, but, perhaps more importantly, this contrasting 'composure and perseverance'. ${ }^{20}$

In fact, South Koreans do have many inconsistent and conflicting attributes. For instance, when there is a 'get-together night' for office workers, everyone is expected to take part in the fun and revelry until very late into the night. They are allowed or encouraged to go to the 
'limits'. Often they are told they should not worry about work the next day. But it turns out that no one is excused for tardiness and laxity, and they are expected to show up on time to work the next day as if nothing had happened.

In Korea, different thoughts and ideologies, religion and culture are all merged to be re-created. During the last 2000 years, Koreans were subjected to Confucianism in every aspect, spiritually as well as in daily life. While China and Japan came into direct contact with Western powers and half-coercively opened their doors to let in capitalism, Korea was more receptive to Western civilization and influence because the US liberated Korea from Japanese colonial rule. Koreans were so envious of Western ideas, science and technology to the point that Koreans' own traditions and values were being discounted, and hence the sense of Korean national identity was seriously curtailed. Korea's traditional values were considered obsolete and the strong sense of urgency to 'change' led to Korea's compressed economic development.

Having achieved modernization in an unprecedented manner and also having experienced the positives and negatives of rapid economic development in a competitive environment, Koreans have started to look back on their history and national identity. As Shin observes, now in Korea, traditional Confucianism and Western capitalism might be heading towards a collision. The ongoing talk of 'economic democracy' in Korea is consistent with the Confucian task of taking care of 'people's economic plight'. Confucianism values equality and humanism, while capitalism is based on competition and materialism. For a long time, Confucian values were seemingly put on the back-burner, but they have been flowing in the veins of Koreans and, according to Shin, are now on the rise.

Koreans may well be at a crossroads in terms of their value system and attitudinal orientations. They have achieved both unprecedented compressed economic development and democratization. Western ideas and system have fuelled the former, while the latter might be attributable to the 're-emergence' of the Confucian values of egalitarianism and humanism. Western countries experienced industrialization and rapid economic growth before realizing democracy, and the Korean model of development is consistent with this modernization. But there is no 
denying that the innate Korean national ethos made this transition possible in such a compressed manner.

$\mathrm{Na}$, Jong-Seok has written a very insightful book on Korea's Confucianism and democracy, in which he claims that Korea was able to achieve democracy based on its traditional Confucian values rather than through its adoption of the Western ideals of democracy. $\mathrm{Na}$ asserts that Korea's democracy has flourished because it is rooted in its Confucianism and, unlike conventional thinking, Confucianism and democracy are not conflicting values. ${ }^{21}$ This may be true, and it provides food for thought for other developing countries struggling with political challenges and social cohesion.

The rise in people's expectations, a rapidly ageing society, the increasing influence of globalization, along with other factors pose new challenges to Korea. As competition and the income gap increase, so does social tension. Furthermore, there are increasing concerns that the youth today are mentally vulnerable and weak. Thus, Korea finds itself in need of once again reflecting on its national values and the way forward. The new developments in the Korean Peninsula surrounding the issue of North Korea's denuclearization, if it continues to make progress, can have no small impact on the national visions.

As Korea fully embarked on the modernization drive, the egalitarianism spirit of Koreans re-emerged, albeit in a different form. The traditional egalitarianism was more of a 'passive' right or idealism bestowed or upheld by the kings and the leaders. The new modern egalitarianism in Korea was born in the very trying conditions, like the struggle against Japanese colonialism, the Korean War and the devastation of the land. As mentioned earlier, the 1950s set the stage for a series of bold reforms like the land reform that revamped the vested interests, leading the way towards a greater egalitarian mindset of the people.

The 1960 s can be seen as a turning point in the history of Korean egalitarianism: 'passive egalitarianism' turned into 'proactive egalitarianism'. This proactive egalitarianism was built on the traditional egalitarianism and humanism with the new 'empowerment of the people' policy pursued by the government. The government's all-out modernization drive propelled the people to be more motivated and 'egalitarian 
minded', and this proactive egalitarianism in turn helped the government's agenda of economic growth and rural development such as the Saemaul Undong. When Korea was well on its way to rapid industrialization, this egalitarian spirit was turning into a formidable force for political change. Korean democracy finally came of age in 1998 with the first-ever peaceful transfer of political power from the ruling party to the opposition party. What seemed impossible happened 'overnight' when votes were tallied for the presidential election, and the perennial opposition leader Kim Dae-Jung was declared the winner.

This showed that Korea is a land of surprises and dynamism that constantly reinvents itself. The year 2002 was marked by the 'eruption' of the Korean people's passion when Korea co-hosted the FIFA World Cup with Japan. It was an important occasion for the Korean people, especially the younger generation, to uplift their pride and confidence, and rediscover themselves. It was also the year when a tragic accident took place, in which two Korean junior high-school girls were hit by a US army armoured vehicle. The US military court's acquittal of the two servicemen in the vehicle sparked unprecedented anti-American sentiments and protests in Korea. In that year, the presidential election was won by Roh Moo-Hyun, the most progressive President the nation had ever seen. Roh's election ushered in a new generation of Korean politicians to power.

\section{The Saemaul Undong (The New Village Movement)}

In the 1960s, Korea posted record growth under the five-year economic development plans, but this policy drive, centred on industrialization, deepened the gap between urban and rural areas. Many people left rural areas to start new lives in the cities, and the growing discontent of the farmers became a political problem. Unemployment and poverty emerged as social issues, and the agricultural sector was faced with labour shortages, causing a rise in agricultural production costs and threatening the viability of the sector. 
President Park Chung-Hee realized that economic development could not be fulfilled without rural development. It was necessary to improve the income of rural households and encourage people to remain in rural areas by providing more income-earning opportunities and employment. This called for drastic measures to reverse the problems caused by the unbalanced growth that was fuelled by rapid industrialization. The Saemaul Undong, which in the beginning had the appearance of a campaign for improving rural living conditions such as roads, housing, water supply, sewage and irrigation, soon turned out to be an all-out movement for transforming the rural sector and the nation as a whole.

The Saemaul Undong is a Korean community development model which contains the spirit of diligence, self-help and cooperation that is also shared in the urban areas as well. It is said that during those times, most rural areas in developing countries, including those in Asia, were trapped in a vicious cycle of poverty, despite the flow of international aid and the government's efforts. In this regard, the World Bank pointed out that it would be difficult to resolve the poverty situation without a special reform programme being in place. $^{22}$

Korea was no exception, and before the Saemaul Undong started in the 1970 s, in rural areas, about $80 \%$ of households were thatched roof houses and only $20 \%$ had an electricity supply. As there were no village entry roads for vehicles, even cultivators could not enter the villages. The situation in Korea back then is comparable to or even worse than what most Sub-Saharan African countries are facing today. But Korea was able to overcome this common and perennial dilemma, the underdevelopment of the rural-agricultural sector of developing countries, and enter the next threshold of development because of the drastic or 'revolutionary' measures initiated by the Korean government in 1970.

Complementing this community movement was the government's efforts to develop new varieties of rice as part of the Green Revolution and conducting large-scale land reclamation projects to create farmland. In the early stages, the Ministry of Internal Affairs played a leading role in this campaign by providing cement and other materials through the local administrative network. Later on, more ministries took part in 
conducting the movement-related programmes, such as assisting rural households to find alternative sources of work out of season, forming cooperatives for the production of rice and barley, supplying electricity to rural areas and building factories.

The Saemaul Undong was launched as a mentally reformative movement to make villagers aware of the spirit of diligence, self-help and cooperation, and a mental reform was achieved through practice and action instead of words and theory. The secret of the Saemaul Undong lies in its practicality, and it was a success because people themselves practised it. As was suggested earlier, the Saemaul Undong could not have been launched at a more opportune time. There was a sense of urgency in the population to get out of the misery in which they found themselves, and with the limited resources they could rely on, it was like they had no other choice but to work hard in order to earn a better living. If Koreans did not embark on such a movement at that time, they could have missed the critical opportunity to do so. It would have become increasingly difficult for the Korean people to take on hardships or make 'sacrifices' for tomorrow as they might have already lost hope or motivation, or have fallen into the sinister trap of the vicious cycle of dependence that we witness today in many Sub-Saharan Africa countries.

The positive thing about the Saemaul Undong was that it bred a virtuous cycle of voluntary collective work producing concrete results, and this reinforced the 'can-do spirit' of the people, which, in turn, brought about competition among villages and widening participation in the movement. The spreading of the Saemaul Undong not only in rural areas but also in urban areas and factories was like a 'wild-fire'. What appears to have helped the farmers to be enthusiastic and confident was that Korea was already witnessing changes in the form of high growth in exports and industrialization in the 1960s.

At the beginning of the movement in 1971, the government is said to have provided 335 sacks ( $40 \mathrm{~kg}$ per sack) of cement to 33,267 villages, leaving it up to the villages to decide for themselves which projects they would use the cement for. As a result, villagers held community meetings in which they elected Saemaul Undong leaders and agreed on which 
projects they would undertake and how they would undertake them following long discussions. For instance, if the villagers decided to construct a village entry road, they would work out specific plans on how to secure the necessary workers and land, and how to acquire and transport gravel and sand, the raw materials needed to make concrete.

The Korean government evaluated the projects of all villages in 1972, one year after enacting the movement, and named 16,600 villages (approximately half of all villages in Korea) as 'outstanding villages'. These outstanding villages were those that had successfully implemented Saemaul Undong projects and were provided with an additional supply of 500 sacks of cement and one ton of steel by the government. The villages that were not given additional government support were stimulated by the government's differentiated support system and, as a result, when all the villages were evaluated again a year later in 1973, some 6000 villages were found to have implemented Saemaul Undong projects with their own resources and without government support.

Against this backdrop, the government classified villages into three categories: basic villages, self-help villages and self-reliant villages. Different projects were implemented in accordance with the level of performance and the level of government support was varied as a result. The principle of prioritized support to successful villages was applied. The strategy of Saemaul Undong can be summed up as being threepronged. First, the government played the role of jump-starting or igniting the villagers' participation by giving limited support to spur the spirit of diligence, self-help and cooperation. Second, villagers started with practical projects in which they can participate and benefit from, and implemented the projects in a democratic process. Third, villagers fully embraced the principle of prioritized support to outstanding villages designed to induce the spirit of self-help and cooperation.

Jai-Chang Lee elaborates and sheds insights on the spirit of the Saemaul Undong: as the Saemaul Undong is a mental reform movement, its underlying spirit is emphasized all the more; however, in the past, many developing countries around the world attempted to develop the rural sector through so-called community development movements without success; the most important reason for their failure was that 
they were devoid of the component of mindset reform given that such type of rural transformation initiatives, in essense, requires mindset reform based on its own social-moral fabric like cultures, traditions and national spirit; this was in contrast to Korea's Saemaul Undong, which was implemented based on the home-grown spirit of diligence, self-help and cooperation. ${ }^{23}$

There are many proverbs that underscore the virtue of the Saemaul Undong spirits: 'the early bird gets the worm (diligence)', 'heaven helps those who help themselves (self-help)' and 'two heads are better than one (cooperation)', to name but a few. In Korea, there was a traditional cooperative agricultural group called durae and a traditional culture called hyangyak, a village code of conduct followed within agricultural communities. These traditional Korean heritages became the basis of the Saemaul Undong spirit, and the people's strong yearning to escape poverty ignited the Saemaul Undong spirit of diligence, self-help and cooperation. ${ }^{24}$

In the initial stage of the Saemaul Undong, the government supplied villagers with basic raw materials such as cement and steel, while providing them with some technical guidelines. The villagers were able to execute by themselves the projects to improve their basic living environment with the backing of the government. For example, kitchens, fences and sewages were modernized in households, and village entry roads were widened and paved, and public laundry facilities as well as public wells were constructed through the Saemaul Undong living environment projects. In addition, training was conducted in order to enlighten villagers with the Saemaul Undong spirit and to nurture their leadership.

The second stage involved building communal infrastructure and implementing production and income-generating projects with the SMU spirit and project experience that had been acquired. The main projects for improving infrastructure included the construction of bridges, clearing of village streams, paving farming roads and building irrigation facilities. Meanwhile, livestock breeding, horticulture, non-agricultural income-generating business, cooperative productions, greenhouse farming and speciality crop farming, such as of herbs, can be cited as examples of the income-generating projects implemented at 
the time. During this stage, professional education on construction and farming as well as mental training was conducted.

In the third stage, various projects for common profit were implemented based on the SMU spirit accumulated through previous projects. Public funds were raised through the Saemaul Undong credit union, cooperative project committees, village stores and the selling of food during special events. In addition, public village facilities such as village libraries, barber shops, baby care centres, public storages, rice mills, workshops and public farming machines were provided.

The fourth stage saw the expansion of the Saemaul Undong to urban areas. SMU, which started as a rural development movement, further developed nationwide during this stage. Urban Saemaul Undong was implemented in the cities by promoting public order, kindness and cleanliness. Energy saving, the promotion of frugal lifestyles and the improvement of product quality as well as productivity were promoted through quality control campaigns in companies and factories.

In more recent times, efforts have been made to promote the Saemaul Undong as a new national movement that can adjust to changes in Korean society under such slogans as 'Green Korea, Smart Korea, Happy Korea, and Global Korea movement'. Good examples of the new Saemaul Undong are the national campaign to gather gold in order to recover from economic crisis, a win-win movement to promote cooperation between employers and employees in businesses, and various social service movements.

Even though great progress was made through the Saemaul Undong, trial and error could not be avoided. But the important thing was that improvements were made as villagers searched for ways to rectify shortcomings in themselves, while the government provided timely and adequate guidelines. ${ }^{25}$

Lastly, according to the Korea Saemaul Undong Centre, the success factors of the Saemaul Undong can be identified as follows: (1) voluntary participation of villagers; (2) democratic decision-making; (3) dedicated leaders; (4) differentiated support by the government; and (5) grassroots-level (village unit) execution. ${ }^{26}$ 


\section{Notes}

1. Joon-Kyung Choi, Upside-Down Success Story of Korea's Economic Development (Seoul: Daewon Publishing, 2013), translated by Christy Hyun-Joo Lee, pp. 6-7.

2. Irma Adelman, 'From Aid Dependence to Aid Independence: South Korea', http://www.un.org/esa/ffd/wp-content/uploads/2007/11/20071116_ IrmaAdelman.pdf.

3. Joong-Kyung Choi (2013), Prologue XX.

4. Dr. Choi, Joong-Kyung, a former chief economic advisor to the President and Minister of Industry, Trade and Energy, also served in the World Bank as Executive Director and was appointed Ambassador to Philippines.

5. Chosun.com (Korean daily news), 1 September 2014, http://pub.chosun.com $/$ client $/$ news $/$ viw.asp? cate $=$ C03\&mcate $=$ M1002\&nNewsNum $b=20140915514 \&$ nid $x=15515$.

6. 'Miracle of South Korea' (2011) (video), http://cafe.daum.net/ yogicflying/Cia1/145214?q(2012.3.1).

7. M.O. Jongryn and Barry R. Weingast, Korean Political and Economic Development_Crisis, Security and Institutional Rebalancing (Cambridge, MA: Harvard University Press, 2013).

8. Ibid., pp. 3-4.

9. Ibid., p. 9.

10. Hyung Ho Park, 2012 Modulation of Korea's Development Experience: Land Reform in Korea (Seoul: Ministry of Strategy and Finance, 2013), p. 121.

11. Jung Jay Joh and Young-Pyo Kim, 'Territorial Development Policy', in Sakong and Koh (2010), p. 183.

12. 'Miracle on the Hand River', DVD made by KDI (2012).

13. Kim Young-Sam, 'Korea Owes RHEE Syngman for the Nation's Egalitarianism', New Daily Korea, 9 April 2014, http://web2.newdaily. co.kr/news/article.html?no=199491.

14. Hyung Ho Park (2013), p. 122.

15. 'Miracle on the Hand River' (2012).

16. Suk-ki Baek, Koreans' Success DNA (Seoul: Maekyung Publications, 2007) (Korean), pp. 122-124.

17. Ibid.

18. Ibid. 
19. Shin Gwang-chul, Extremist Koreans, Extreme Creativity (Seoul: Sam \& Parkers, 2013).

20. Ibid., pp. 30-32.

21. Jong-seok Na, Daedong Democratic Confucianism and 21st Shilhak (Seoul: Dosochulpanb, 2017) (Korean).

22. 'Saemaul Undong in Korea', lecture given by Jai Chang Lee, President of the Korea Saemaul Undong Centre at Makerere University, Kampala, Uganda, 19 October 2012.

23. Ibid. Joong-Kyung Choi, in Upside-Down Success Story of Korea's Economic Development (2013), points out that many countries including China have tried to emulate the Saemaul Undong, and the Saemaul Undong in development economics is understood as a concept of Community-Driven Development (CDD) and is promoted as one of the main policy items by international organizations like the World Bank; however, the CDD is more of a NGO-led social development programme and thus differs from the prototype of the Saemaul Undong, which is self-help.

24. Ibid.

25. Typical mistakes or shortcomings include villagers being faced with technical gaps in the process of autonomous implementation. For example, there were cases of large bridges constructed by villagers breaking down after a while due to villagers' lack of technical skills; in some instances, villagers were burdened by some projects that were beyond their capacity of implementing. This is the consequence of too much emphasis on competition; also, some village projects aimed at only 'visible' results.

26. To elaborate, villagers' voluntary participation was induced through efficient and timely support from the government. Villagers became participative as their confidence was raised through the possibility of economic development and rural improvements as part of the government's efforts to make Korea industrialized. Second, Saemaul projects were implemented in a democratic way in which villagers made their own decisions. The government only provided technical guidelines, while villagers elected Saemaul leaders and selected the projects to conduct in their villages. This autonomous policy induced the spontaneous participation of villagers. Third, there were dedicated Saemaul leaders and their strong leadership was nurtured by the Saemaul Undong. The Saemaul leaders were unpaid voluntary workers who were elected 
by villagers and played the role of a leader based on the Saemaul training they received at the Saemaul Undong Central Training Institute. Saemaul awards were given to leaders in accordance with their accomplishments to raise their morale. Fourth, the government prioritized support to well-performing villages to induce competition based on self-help spirit. The government also differentiated its level of support to villages categorized into three levels: basic villages, self-help villages and self-reliant villages. As a result, villagers worked harder on their projects to upgrade their village level and receive more support from the government. Fifth, Saemaul projects were executed in village units. Traditional villages in Korea were able to bring about cooperative spirit and common profit that worked for the Saemaul Undong (Jai Chang Lee, 2012).

Open Access This chapter is licensed under the terms of the Creative Commons Attribution 4.0 International License (http://creativecommons. org/licenses/by/4.0/), which permits use, sharing, adaptation, distribution and reproduction in any medium or format, as long as you give appropriate credit to the original author(s) and the source, provide a link to the Creative Commons license and indicate if changes were made.

The images or other third party material in this chapter are included in the chapter's Creative Commons license, unless indicated otherwise in a credit line to the material. If material is not included in the chapter's Creative Commons license and your intended use is not permitted by statutory regulation or exceeds the permitted use, you will need to obtain permission directly from the copyright holder.

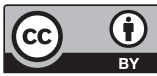

